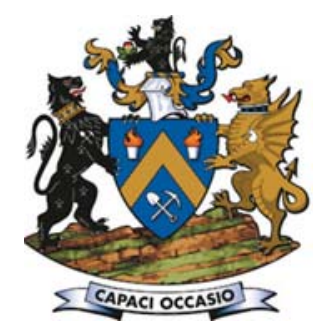

\title{
The role of pulp potential and the sulphidization technique in the recovery of sulphide and oxide copper minerals from a complex ore
}

\author{
by M. Kalichini*‡, K.C. Corin*, C.T. O'Connor*, and \\ S. Simukanga ${ }^{\dagger}$
}

\section{Synopsis}

Kansanshi copper mine is situated in the northwestern province of Zambia. Weathering has given rise to a vertically zoned profile comprising leached, refractory, oxide, mixed, and hypogene sulphide mineralization. As a result of the mineral variations, the processing plant treats three distinct ore types, viz. oxide, sulphide, and mixed. The objective of this study was to investigate the floatability of a complex Kansanshi mixed copper ore comprising sulphide and oxide minerals, with a view to achieving an optimal flotation performance in the treatment of the Kansanshi orebody, with a special focus on the sulphidization process. This required an indepth analysis of the mineralogy of the feed as well as tailings samples after different flotation processes involving a range of reagent types and dosage procedures. Controlled potential sulphidization (CPS) has been adopted over slug sulphidization as the industry standard for the recovery of oxide copper minerals through flotation. Two potential ranges were investigated in this study; -300 to $-400 \mathrm{mV}$ and -400 to $-500 \mathrm{mV}$. Optimum flotation performance was observed in the potential range of -300 to -400 $\mathrm{mV}$ and a NaHS:SIBX ratio of 7:1 during CPS. CPS was also found to be economically superior to slug addition.

Keywords sulphidization, copper oxide minerals, flotation.

\section{Introduction}

Kansanshi copper mine is situated in the northwestern province of Zambia. Unlike the stratiform deposits common to the Zambian Copperbelt, mineralization in the Kansanshi deposit occurs in quartz-carbonate veins, with the lowest exposed rock unit being the basal limestone comprising albite $\left(\mathrm{NaAlSi}_{3} \mathrm{O}_{8}\right)$, dolomite $\left(\mathrm{CaMg}\left(\mathrm{CO}_{3}\right)_{2}\right)$, minor muscovite $\left(\mathrm{KAl}_{2}\left(\mathrm{Si}_{3} \mathrm{Al}\right) \mathrm{O}_{10}(\mathrm{OH}, \mathrm{F})_{2}\right)$, chlorite, and dispersed sulphides (Speiser, Hein, and Porada, 1995; Broughton, Hitzman, and Stephens, 2002). While the Copperbelt ores are enriched in cobalt (Selley et al., 2005), the Kansanshi deposit contains miniscule amounts of cobalt - less than 50 ppm (Broughton, Hitzman, and Stephens, 2002).

Copper oxide minerals form as a result of supergene processes that occur when copper sulphide minerals are exposed to the effects of weathering (Reich et al., 2009) and encompass a series of defined assemblages that reflect a variable $\mathrm{pH}$, oxidizing geochemical environment, known as the oxide zone, in which the source rock, host rock mineralogy, and iron-copper sulphide mineral abundance, among other factors, determined which oxide mineral formed (Chavez, 2000). Broughton, Hitzman, and Stephens (2002) surmised that in the Kansanshi deposit, weathering has given rise to a vertically zoned profile comprising leached, refractory, oxide, mixed, and hypogene sulphide mineralization, with the thickness of the various mineraliation facies being dependent on vein abundance, the quantity of acid-forming sulphides, and the stratigraphic level in relation to carbonatebearing lithologies. The ore deposit contains both primary and secondary copper minerals and is therefore classed into three distinct types, viz. sulphide, oxide, and mixed. The mixed ore contains oxide, supergene oxide, and hypogene sulphide copper species, with the greater part of the deposit being made up of sulphide and mixed ores. The oxide ore has a much higher copper grade than the mixed and sulphide ores but contributes less to the resource (Broughton Hitzman, and Stephens, 2002).

In the last couple of decades, research in this area has focused on the need for a better understanding of the mineralogy of oxide ores being treated (O'Meara, 1961; Lee, Nagaraj, and Coe, 1998; Lee et al., 2009), as this gives an indication of mineral associations, inclusions, liberation, as well as gangue mineralogy, all of which have profound effects on flotation. When oxide copper minerals are hosted in a matrix of acid-consuming gangue such as calcite, acid leaching becomes an uneconomic processing option and froth flotation is the preferred process. Where the oxides are chemically well defined, as in the case of malachite, flotation is relatively easy (Phetla and Muzenda, 2010; Lee, Nagaraj, and

\footnotetext{
* University of Cape Town, South Africa.

+ University of Zambia, Lusaka, Zambia.

‡ First Quantum Minerals Ltd, Kansanshi Mine, Solwezi, Zambia.

(c) The Southern African Institute of Mining and Metallurgy, 2017. ISSN 2225-6253. Paper received Dec. 2016; revised paper received Feb. 2017.
} 


\section{The role of pulp potential and the sulphidization technique}

Coe, 1998; Lee et al., 2009; Hope, Woods, and Parker, 2010; Hope et al., 2012). This is not the case with chrysocolla, however, because of its amorphous nature (McKeown, 1994; Hope et al., 2012).

Sulphidization as a method of promoting the recovery of oxidized ores was patented in 1905 (Schwarz, 1905) and has since been developed and adapted as the preferred pretreatment method prior to the flotation of oxide and mixed copper ores containing both oxides and sulphides. The reagents used in this technique of activating base metal oxides are alkali sulphides (Soto and Laskowski, 1973) such as sodium sulphide $\left(\mathrm{Na}_{2} \mathrm{~S}\right)$ and sodium hydrosulphide (NaHS). Slug sulphidization, in which the sulphidizing agent is added to the pulp in a single slug dose, has been investigated (Jones and Woodcock, 1979; Quast et al., 2005) but is generally not preferred because of the difficulty in controlling the pulp potential, thus leading to poor mineral recoveries due either to under-sulphidizing or depression of minerals due to over-sulphidizing. Controlled potential sulphidiation (CPS) has been applied in numerous operations around the world, including Zambia (Chabuka and Witika, 2001; Wills and Napier-Munn, 2006), the Democratic Republic of Congo (Ferron and Manu, 1994) and China (Wenbin, 1993).

Generally, CPS gives better results than slug sulphidization in laboratory studies. These results are, however, difficult to reproduce at plant scale. '...The main drawback of CPS is that the optimum dose of the sulphidising agent is highly dependent on the time of conditioning, procedures of mixing and other variables, leading usually to poor reproducibility in a plant situation.' (Lee et al., 2009). The change in the nature of the feed also has an effect on CPS (Jones and Woodcock, 1979). Nagaraj and Gorken (1991) suggested that the use of an on-stream analyser could eliminate the uncertainty in dosing NaHS and possibly minimize the necessity of changing the collector dosage. A wide range of potentials have been proposed as 'optimum' in the CPS of malachite-rich ores, viz. -300 to $-380\left(E_{S}\right) \mathrm{mV}$ (Feron and Manu, 1994), $-500\left(E_{S}\right) \mathrm{mV}$ (Quast et al., 2005), and $+50\left(E_{h}\right) \mathrm{mV}$ or $+250\left(E_{h}\right) \mathrm{mV}$, depending on the concentration of the sulphidizing agent (Soto and Laskowski,
1973), where $E_{h}$ is the oxidation-reduction potential as measured by a platinum electrode, while $E_{S}$ is the potential value of an ion-selective electrode such as $\mathrm{Ag} / \mathrm{AgCl}$. The potential has also been shown to be dependent on the concentration of the sulphidizer (Soto and Laskowski, 1973), the nature of the sulphidizing agent used (Quast et al., 2005), and the overall pulp chemical conditions (Feron and Manu, 1994).

The objective of this study was to investigate the floatability of a complex Kansanshi mixed copper ore comprising sulphide and oxide minerals with a view to achieving an optimal flotation performance in the treatment of the Kansanshi orebody. This required an in-depth analysis of the mineralogy of the feed, as well as tailings samples after different flotation processes using a range of reagent types and dosage procedures. The focus on the mineralogical study of tailings rather than concentrate was to identify those minerals that did not respond favourably to the various flotation procedures used. This also addressed the question regarding the relative roles of the sulphidizer in contributing either to the flotation of possibly tarnished chalcopyrite particles or to the flotation of oxides such as chrysocolla which are associated with chalcopyrite.

\section{Experimental methods}

A high-grade sample of mixed ore was obtained by belt-cut at Kansanshi. The sample assayed $1.17 \% \mathrm{Cu}$. Mineralogical analysis was performed using a LEO SEM-based QEMSCAN QS18 platform equipped with two Bruker 4010 SDD detectors for all analyses.

A $1 \%(w / v)$ sodium isobutyl xanthate, SIBX, collector stock solution was made up to be dosed as required for each test. The frother, Dow200, was used as provided. A 10\% (w/v) stock solution of sulphidizing agent, NaHS, was made up to be dosed as required for each test.

An Eriez Magnetics ${ }^{\circledR}$ MASCLAB belt-driven stainless steel laboratory-scale rod mill was used for all milling in the test work. The mill had an internal diameter of $200 \mathrm{~mm}$ and a length of $297 \mathrm{~mm}$, and was charged with 20 mild steel rods of three diameters, viz. six $16 \mathrm{~mm}$, eight $20 \mathrm{~mm}$, and six
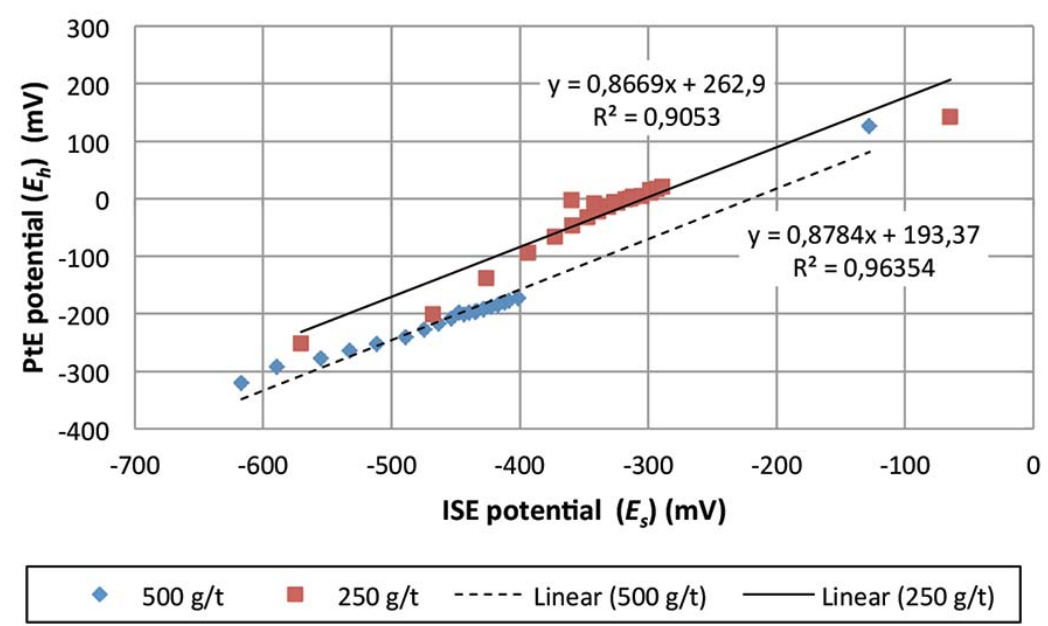

Figure 1-Relationship between $E_{h}$ and $E_{s}$ 


\section{The role of pulp potential and the sulphidization technique}

$25 \mathrm{~mm}$ rods. All flotation tests were carried out in triplicate in a 3 L Barker flotation cell. The cell is made of clear Perspex to enable visual control of froth depth and is fitted with a topdriven variable speed impeller. Flotation was carried out at an impeller speed of $1500 \mathrm{r} / \mathrm{min}$ and air flow rate of $7 \mathrm{~L} / \mathrm{s}$. Various electrode systems were used to monitor the pulp chemistry during sulphidization. A YSI 556 MPS multi-probe system was used to measure and log the temperature, $\mathrm{pH}$, dissolved oxygen (DO), and redox potential ( $v S$ SHE) $\left(E_{h}\right)$ of the system, and the sulphidization potential, $E_{S}$, was measured using a HANNA silver/silver-chloride ion-selective electrode (ISE) and HANNA HI 8424 meter. The main difference between the two meters is that the YSI $(\mathrm{Pt})$ is capable of data logging, whereas the HANNA (Ag/AgCl) system is not. The use of the two pulp potential probes was aimed at determining the relationship, if any, between $E_{h}$ and $E_{S} . E_{h}$ and $E_{S}$ potentials of continuously stirred LQ ore were monitored after slug addition of $250 \mathrm{~g} / \mathrm{t}$ and $500 \mathrm{~g} / \mathrm{t}$ of NaHS. Figure 1 shows the linear relationship between the two expressions within defined potential ranges; -300 to -400 $\mathrm{mV}$ and -400 to $-500 \mathrm{mV}$. Since the YSI (Pt) electrode showed more consistent readings as well as the ability to measure more than one parameter, this electrode was used throughout the test work.

A grind size of $80 \%$ passing $150 \mu \mathrm{m}$ was chosen to replicate site conditions. Bearing in mind that this ore contained both sulphide and oxide copper minerals, the flotation procedures developed focused on optimizing firstly the sulphide mineral recovery and then the oxide mineral recovery by investigating CPS. A schematic of the flotation procedures is given in Figure 2. Sulphide mineral recovery tests were conducted over 10 minutes, during which four concentrates were collected. After determining the dosage and time required for optimum sulphide mineral recovery, two different sulphidization techniques were investigated. The first set of sulphidization tests used slug sulphidization. In the case of CPS, the same initial procedure was followed. However, at the point of NaHS addition, three sulphidization stages were added to the flotation procedure and two potential ranges were investigated. The NaHS dosage was determined by the potential range that was targeted namely 300 to $-400 \mathrm{mV}$ or -400 to $-500 \mathrm{mV}$. The total NaHS dosages required throughout the tests were $219 \mathrm{~g} / \mathrm{t}$ and $397 \mathrm{~g} / \mathrm{t}$ respectively. The conditioning time for each NaHS addition was 3 minutes. Three NaHS:SIBX ratios were investigated within each sulphidization stage, viz. 20:1, 10:1, and 7:1. The conditioning time after each SIBX addition was 2 minutes. The third, fourth, and fifth concentrates were collected for 3 minutes each, during which time the potential may have increased, requiring further NaHS addition in the second and third sulphidization stages.

\section{Results}

\section{Mineralogy of the ore}

The bulk mineralogy of the ore as determined by QEMSCAN is given in Table I. The ore contained both sulphide and oxide copper minerals. The two most abundant copper minerals were chrysocolla $(3.8 \mathrm{wt} \%)$ and chalcopyrite $(1.0 \mathrm{wt} \%)$. The major gangue minerals in the ore were calcite $(29.1 \mathrm{wt} \%)$, plagioclase feldspar (23.8 wt\%), and quartz (16.4 wt\%).

Table II shows the copper deportment in the ore. $63.1 \%$ of the copper reported as chrysocolla, $22.2 \%$ as chalcopyrite, $1.5 \%$ as cuprite, and $2.9 \%$ as malachite/azurite. The focus of the study was therefore on chalcopyrite and chrysocolla because they were the two most abundant copper minerals.

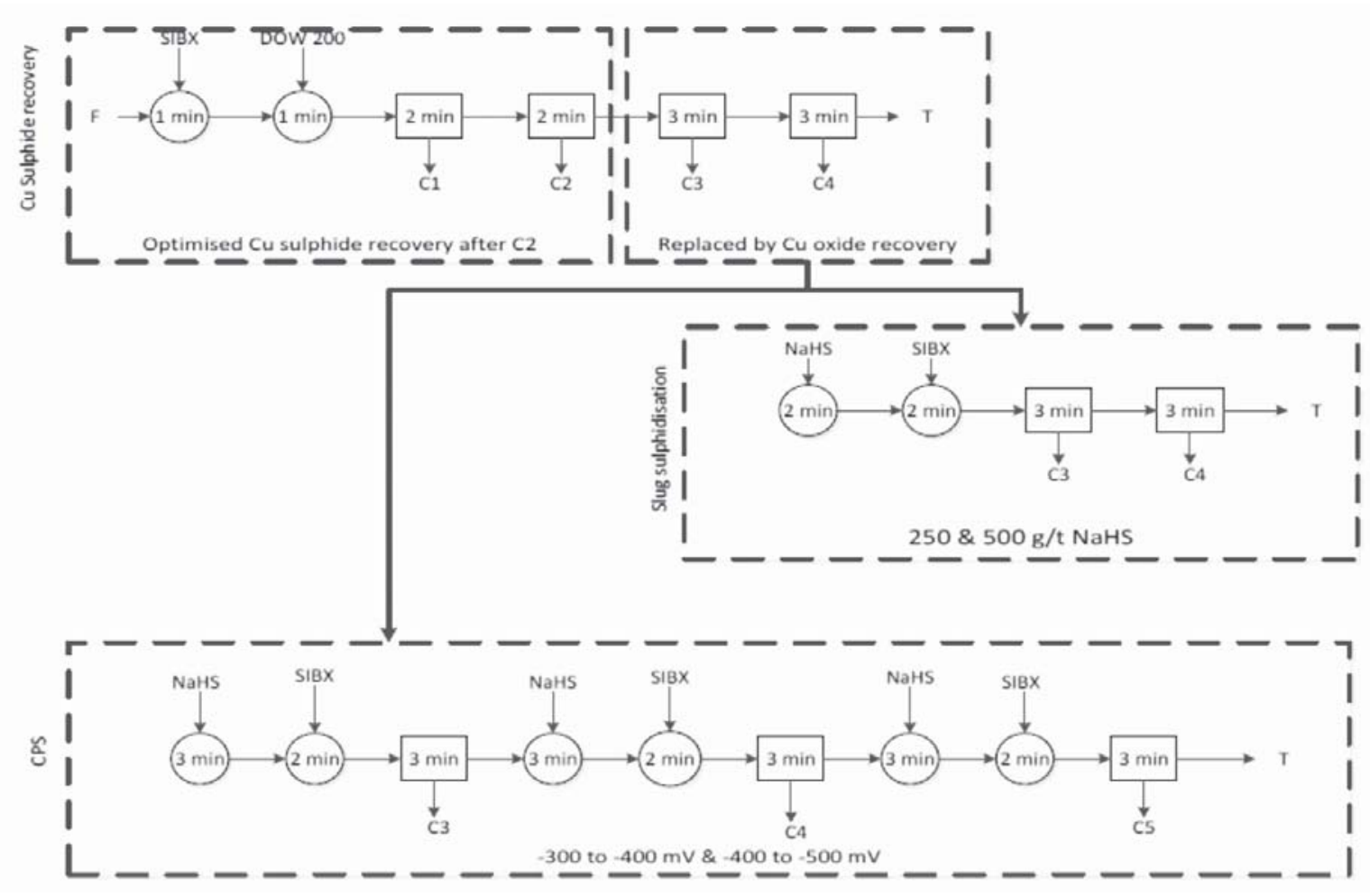

Figure 2-Schematic of flotation procedures 


\section{The role of pulp potential and the sulphidization technique}

\begin{tabular}{|c|c|}
\hline \multicolumn{2}{|c|}{$\begin{array}{l}\text { Table I } \\
\text { Bulk mineralogy of the mixed ore }\end{array}$} \\
\hline Mineral & Average content (wt $\%)$ \\
\hline Pyrite & 1.0 \\
\hline Pyrrhotite & 0.7 \\
\hline Chalcopyrite & 1.0 \\
\hline Bornite & $>0.1$ \\
\hline Covellite & $>0.1$ \\
\hline Other sulphides & 0.1 \\
\hline Cuprite & $>0.1$ \\
\hline Malachite/azurite & 0.1 \\
\hline Chrysocolla & 3.8 \\
\hline Amphibole & 3.8 \\
\hline Mica & 9.2 \\
\hline Kaolinite & 1.7 \\
\hline Plagioclase feldspar & 23.8 \\
\hline Quartz & 16.4 \\
\hline Calcite & 29.1 \\
\hline $\mathrm{Fe}-\mathrm{Ti}$ minerals & 1.1 \\
\hline Limonite & 6.7 \\
\hline Others & 1.7 \\
\hline
\end{tabular}

Table III

\section{Liberation criteria used in mineralogical analysis}

\begin{tabular}{l|c}
\hline Criterion & Area percentage mineral exposed \\
\hline Liberated & $\geq 90 \%$ \\
\hline Middlings & $90-30 \%$ \\
\hline Locked & $\leq 30 \%$
\end{tabular}

The liberations of chalcopyrite and chrysocolla were determined using QEMSCAN. Table III shows the definitions of liberation used.

Figure 3 shows the extent of liberation of chalcopyrite and chrysocolla. About $29.8 \%$ of the chrysocolla $(1.1 \%$ of the $3.8 \%$ in the ore) and $51.5 \%$ of the chalcopyrite $(0.5 \%$ out of the $1.0 \%$ in the ore) were fully liberated. Association data indicated that the chalcopyrite was mostly associated with chrysocolla, viz. $42.9 \%$ of the chalcopyrite was associated with chrysocolla and $3.9 \%$ with malachite. Most of the chrysocolla was associated with limonite, viz. 39.4\%. 1.26\% of the chrysocolla was associated with malachite and $4.0 \%$ with chalcopyrite.

\section{Batch flotation}

\section{Tests using SIBX}

Initial tests were conducted to optimize chalcopyrite and secondary copper sulphide mineral recovery using SIBX. Collector dosages of $20 \mathrm{~g} / \mathrm{t}, 30 \mathrm{~g} / \mathrm{t}$, and $50 \mathrm{~g} / \mathrm{t}$ were investigated. Figure 4 shows the grade-recovery results for these tests. Both $\mathrm{Cu}$ recovery and grade increased with an increase in collector dosage from $20 \mathrm{~g} / \mathrm{t}$ to $30 \mathrm{~g} / \mathrm{t}$, but decreased when the dosage was increased to $50 \mathrm{~g} / \mathrm{t} .30 \mathrm{~g} / \mathrm{t}$ SIBX gave the highest $\mathrm{Cu}$ recovery $(24.7 \%)$ at a grade of $14.5 \%$ and was thus selected as the best dosage from the three values tested for sulphide mineral recovery. The tailings from the $30 \mathrm{~g} / \mathrm{t}$ SIBX test were subjected to mineralogical analysis using QEMSCAN. Table IV shows that $5.8 \%$ of the copper that was not recovered was chalcopyrite and $1.2 \%$ was malachite, but the bulk of the copper in the tailings was hosted in chrysocolla, viz. $78.8 \%$.

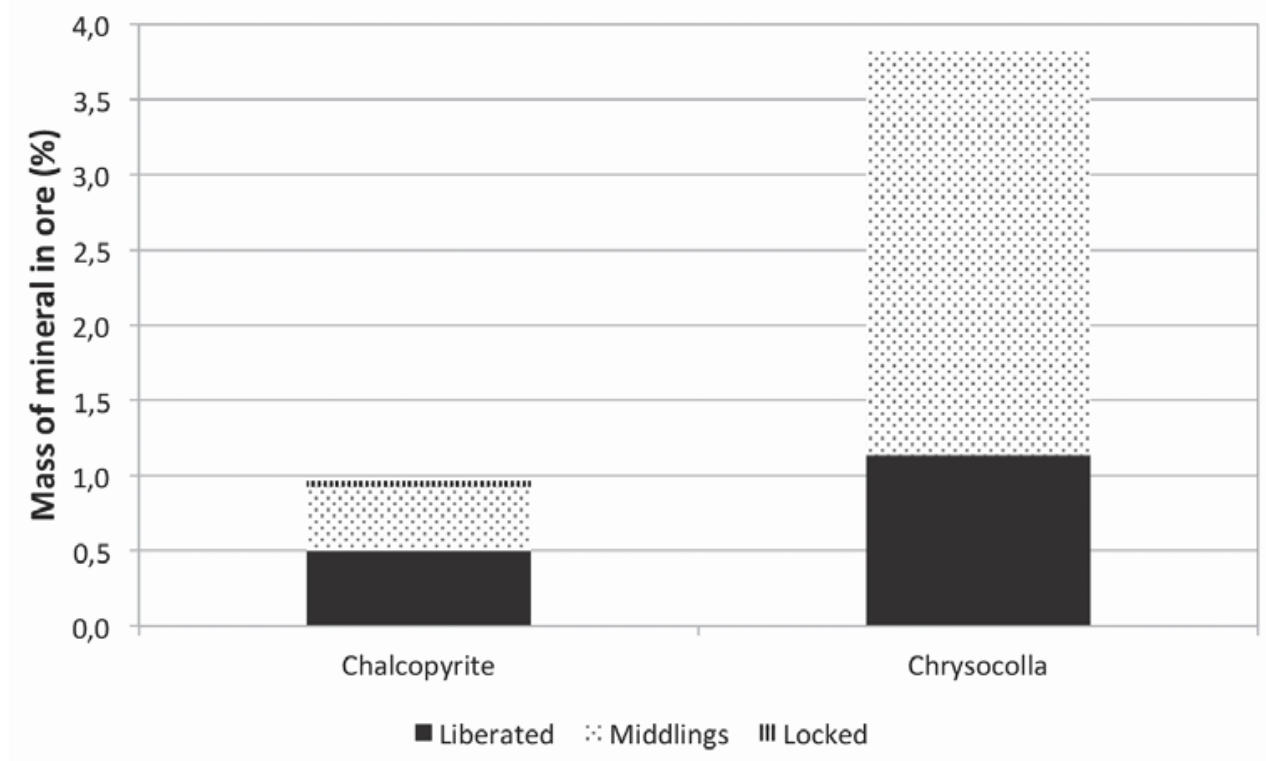

Figure 3-Chalcopyrite and chrysocolla liberation 


\section{The role of pulp potential and the sulphidization technique}

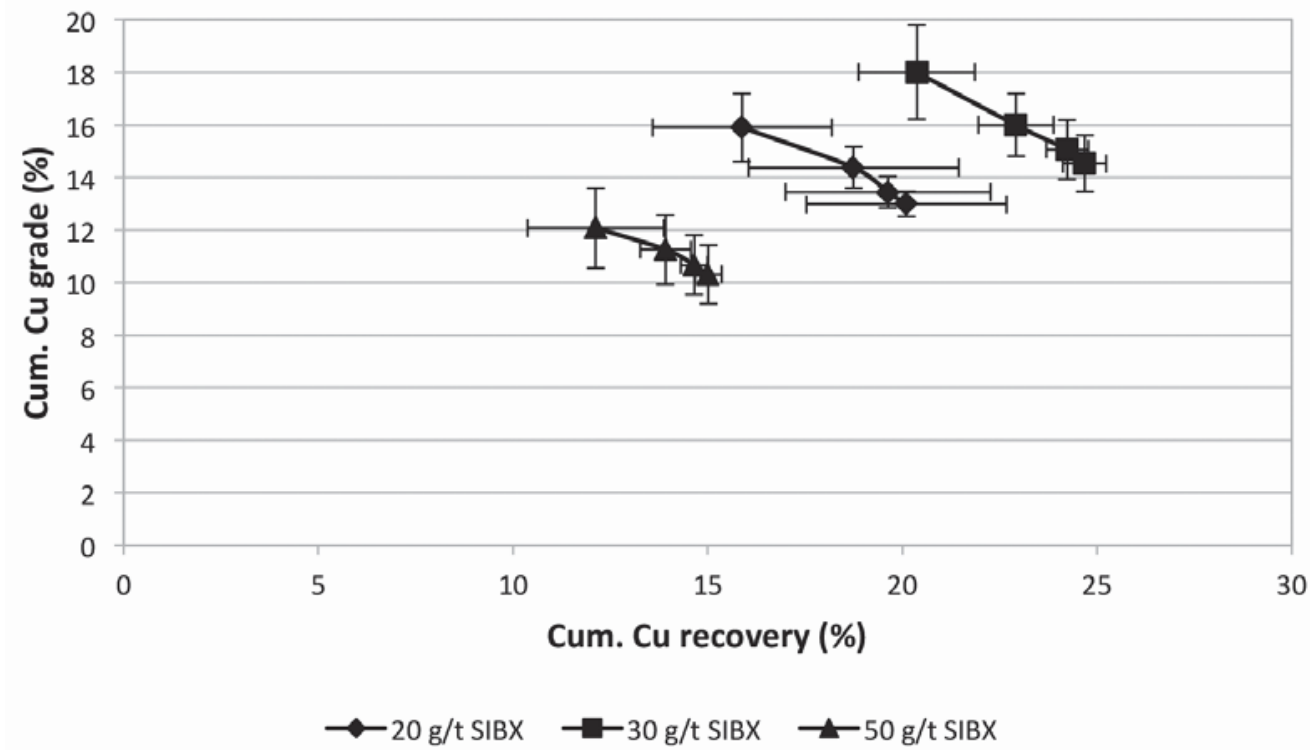

Figure 4-Cu grade versus recovery for flotation of mixed ore with $20 \mathrm{~g} / \mathrm{t}, 30 \mathrm{~g} / \mathrm{t}$, and $50 \mathrm{~g} / \mathrm{t} \mathrm{SIBX}$

Table IV

\section{Copper deportment of tailings after flotation with $30 \mathrm{~g} / \mathrm{t} \mathrm{SIBX}$}

\begin{tabular}{|l|c|}
\hline Mineral & Cu deportment (\%) \\
\hline Chalcopyrite & 5.8 \\
Bornite & 0.3 \\
Chalcocite/digenite & 0.1 \\
Covellite & 0.2 \\
Cuprite & 1.1 \\
Malachite/azurite & 1.3 \\
Chrysocolla & 78.8 \\
Mica & 0.1 \\
Kaolinite & 8.6 \\
Plagioclase feldspar & $>0.1$ \\
Quartz & $>0.1$ \\
Limonite & 3.8 \\
\hline
\end{tabular}

\section{Effect of adding NaHS}

It can be seen from Figure 5 that introducing NaHS into the pulp, regardless of whether the reagent was added using the slug or CPS addition technique, led to increased solids and water recovery. This phenomenon was also observed by Becker et al. (2014), who noted that the addition of NaHS in the absence of a hydroxamate collector increased water recovery when compared to a test in which only SIBX was added. This appears to indicate that the NaHS also plays a froth stabilizing role. For the slug sulphidization procedure in particular, increasing the NaHS dosage from $250 \mathrm{~g} / \mathrm{t}$ to 500 $\mathrm{g} / \mathrm{t}$ resulted in a $41 \%$ increase in water recovery from $237 \mathrm{~g}$ to $333 \mathrm{~g}$ with a negligible increase in solids recovery (31.13 $\mathrm{g}$ to $31.52 \mathrm{~g}$ ). Using the CPS procedure resulted in an even greater increase in water recovery compared to tests without NaHS or using slug addition. The solids recoveries were almost twice those with only SIBX, and greater than those in

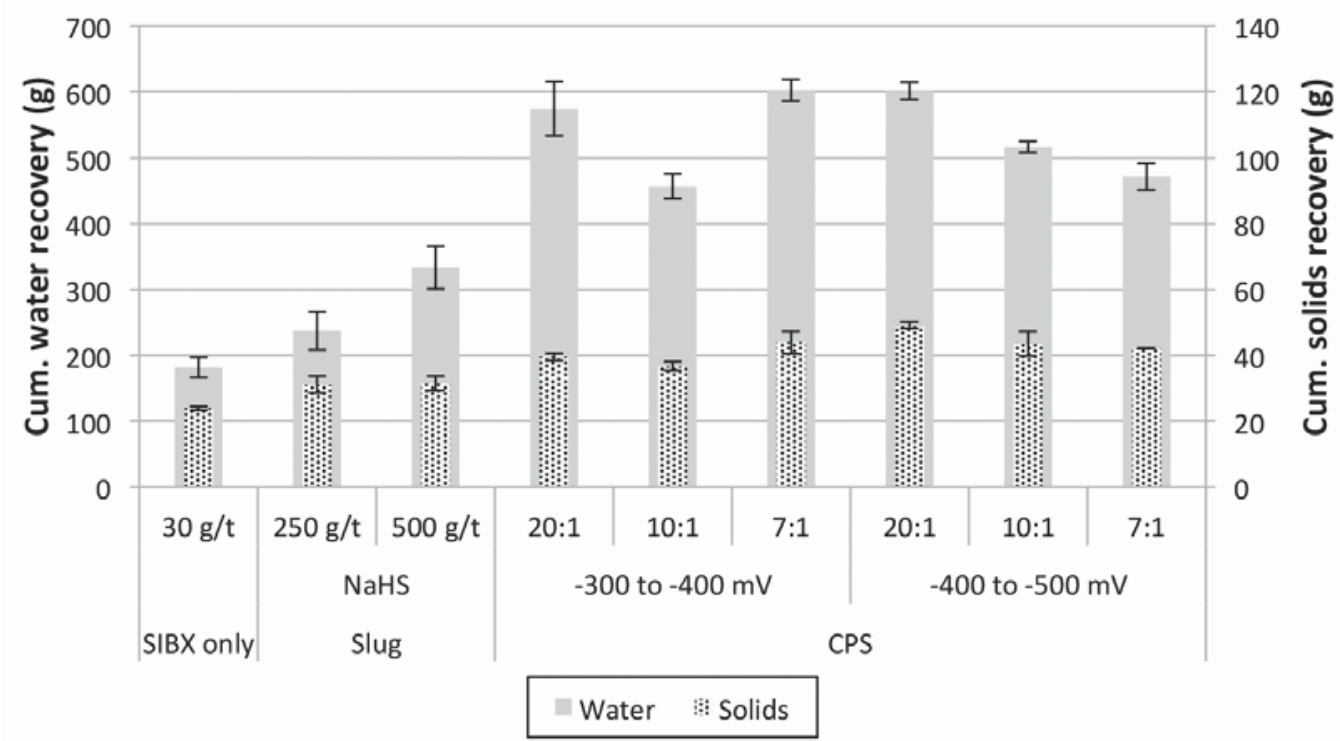

Figure 5-Cumulative solids and water recoveries for the flotation of mixed ore with $30 \mathrm{~g} / \mathrm{t} \mathrm{SIBX}$, followed by slug sulphidization with $250 \mathrm{~g} / \mathrm{t}$ and $500 \mathrm{~g} / \mathrm{t}$ NaHS and CPS at -300 to $-400 \mathrm{mV}$ and -400 to $-500 \mathrm{mV}$ using NaHS:SIBX ratios of 20:1, 10:1, and 7:1 


\section{The role of pulp potential and the sulphidization technique}

the case of slug addition. It is important to note that in the case of CPS when adding NaHS to control the potential in the range of -300 to $-400 \mathrm{mV}$, the total NaHS addition was 219 $\mathrm{g} / \mathrm{t}$, but in the case of the higher potential range of -400 to $500 \mathrm{mV}$ it was $397 \mathrm{~g} / \mathrm{t}$. It should be noted that a fifth concentrate was included in these tests, which may induce higher solids and water recoveries.

The increase in solids recovery after the introduction of NaHS, whether by slug addition or CPS, can be attributed partly to the recovery of oxide minerals that were not recovered during flotation with SIBX only. It is noteworthy that the increase was greater in the case of CPS than for slug addition. The grade-recovery trends are summarized in Figure 6 . In the case of slug addition, $\mathrm{Cu}$ recovery increased with increasing NaHS addition. The same observation has been made in the case of slug sulphidization of oxidized lead-zinc-silver material with $\mathrm{Na}_{2} \mathrm{~S}$ (Jones and Woodcock, 1979) and malachite with calcium polysulphide (Quast et al., 2005). CPS addition of NaHS also increased Cu recovery when compared to the base case ( $30 \mathrm{~g} / \mathrm{t} \mathrm{SIBX),} \mathrm{although} \mathrm{the}$ grades were lower, thus illustrating that NaHS addition using the CPS method increased the mass pull. Clearly, NaHS plays a role in enhancing the recovery of the oxides of copper. In fact, the average $\mathrm{Cu}$ recovery when NaHS was added did not vary significantly when comparing slug and CPS addition procedures. In both cases the average recovery was in the region of $30 \%$.

In the case of CPS, the highest solids recoveries were paired with the highest water recoveries for both potential ranges. CPS addition of NaHS also resulted in a significant increase in $\mathrm{Cu}$ recovery from the $22.9 \%$ observed for the base case ( $30 \mathrm{~g} / \mathrm{t}$ SIBX) to an average of about $30 \%$. However, CPS treatment resulted in a general decrease in grade, from approximately $15 \%$ to $10 \%$, compared to slug sulphidization. This indicates a greater but unselective mass pull of solids into the concentrate, thus reducing the copper grade. This is an interesting result, since the highest water recoveries were also observed in CPS. This relationship between solids and water recovery is typical of a greater degree of entrainment of non-floatable minerals. Clearly, the CPS method results in greater true flotation of oxide minerals, but there is also an increased recovery of gangue minerals due to the higher water recovery, which is indicative of a greater froth stability.

The tailings after slug sulphidization treatment with 500 $\mathrm{g} / \mathrm{t}$ NaHS were subjected to mineralogical analysis, and the copper deportment is illustrated in Table V. Two important observations arise. Firstly, comparison of the above results to those shown in Table $\mathrm{V}$ indicates that all of the chalcopyrite that had not been recovered in the pre-sulphidization stage was recovered after sulphidization. This is consistent with the recoveries of $22.9 \%$ without sulphidization (loss of $5.8 \%$ to the tailings) and 30\% recovery after sulphidization with essentially no chalcopyrite reporting to the tailings. Since the chalcopyrite in the feed to sulphidiation had been shown to be mostly liberated, it is possible that some of it had become tarnished due to in situ weathering or during storage and

\section{Table $V$ \\ Copper deportment in tailings after slug sulphidization with $500 \mathrm{~g} / \mathrm{t}$ NaHS}

\begin{tabular}{|l|c|}
\hline Mineral & Cu deportment (\%) \\
\hline Chalcopyrite & 0.80 \\
Bornite & 0.06 \\
Chalcocite/digenite & 0.1 \\
Covellite & 0.10 \\
Cuprite & 0.09 \\
Malachite/dzurite & 0.63 \\
Chrysocolla & 84.79 \\
Mica & 0.14 \\
Kaolinite & 9.15 \\
Plagioclase feldspar & $>0.1$ \\
Quartz & $>0.1$ \\
Limonite & 4.18 \\
\hline
\end{tabular}

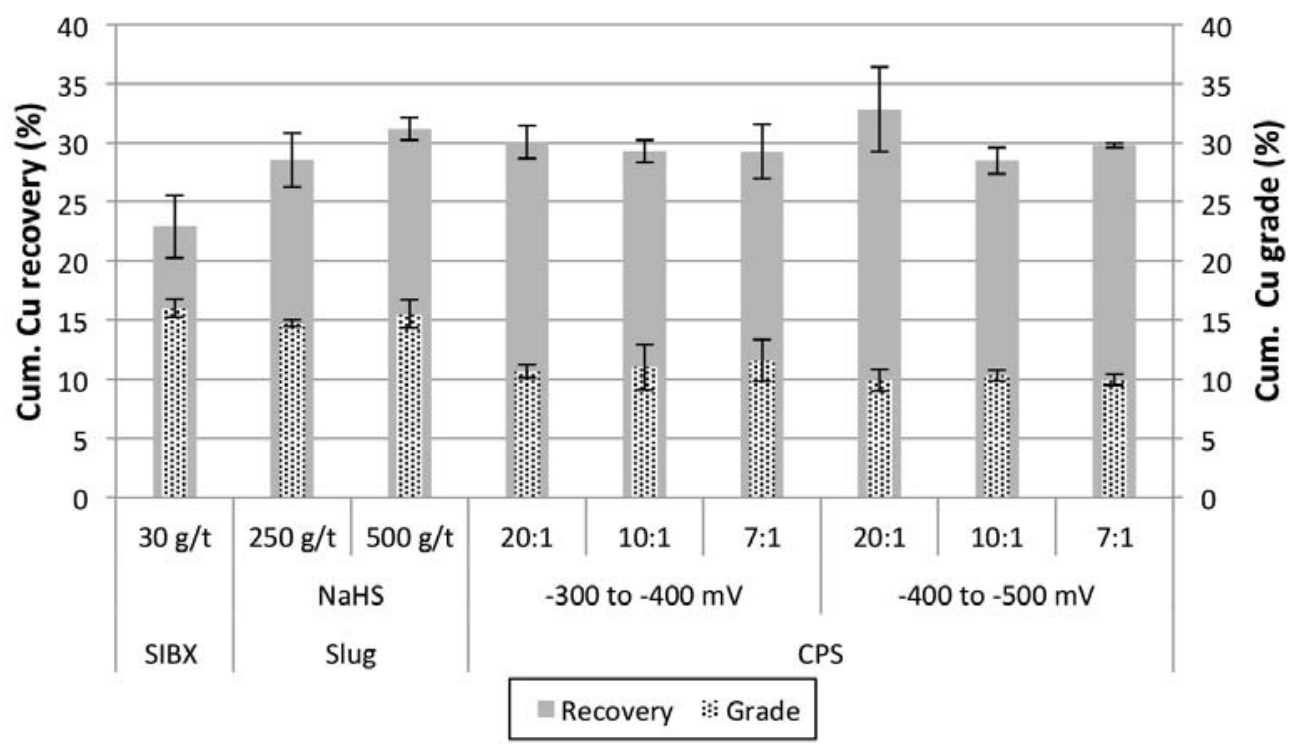

Figure 6-Cumulative grade-recovery trends for the sulphidization-flotation of mixed ore with $30 \mathrm{~g} / \mathrm{t}$ SIBX, followed by slug sulphidization with $250 \mathrm{~g} / \mathrm{t}$ and $500 \mathrm{~g} / \mathrm{t} \mathrm{NaHS}$ and CPS at potential ranges of -300 to $-400 \mathrm{mV}$ and -400 to $-500 \mathrm{mV}$ using NaHS:SIBX ratios of 20:1, 10:1, and 7:1 


\section{The role of pulp potential and the sulphidization technique}

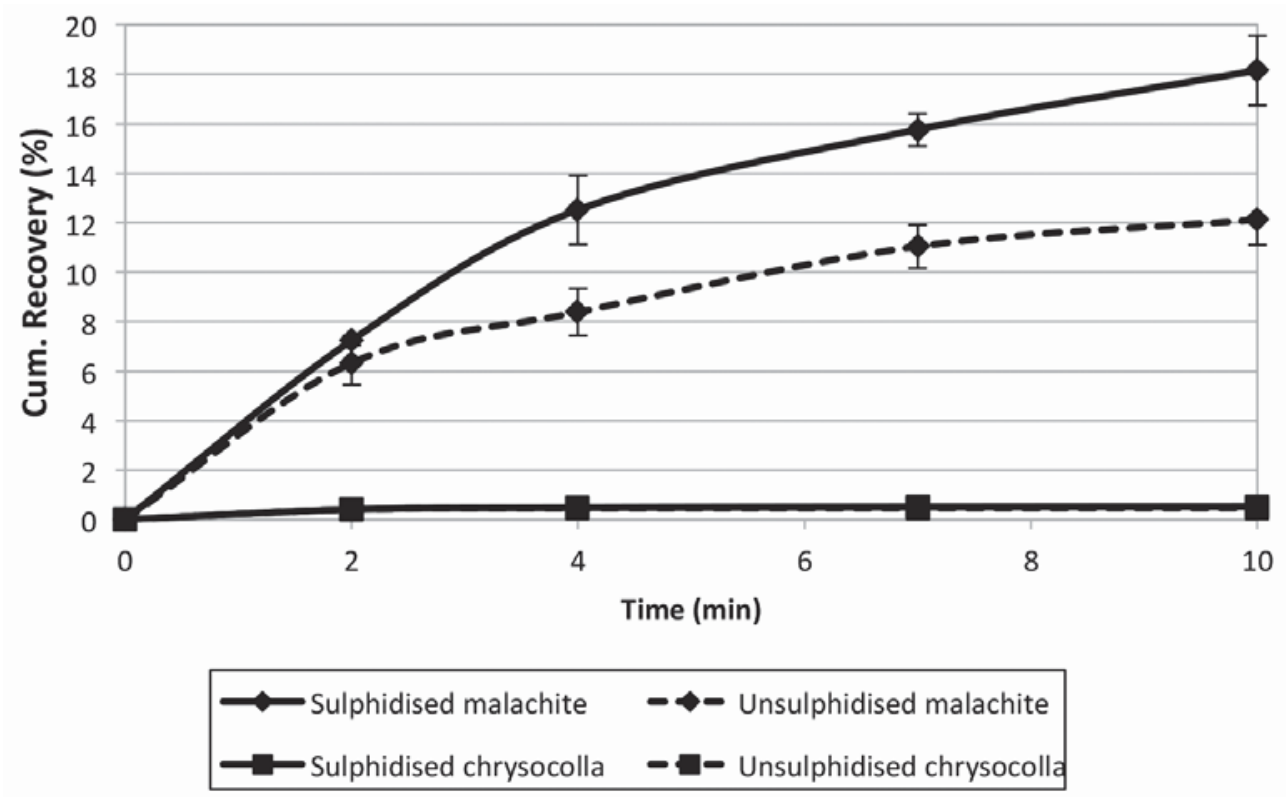

Figure 7-Recovery-time plots for the microflotation of pure malachite and chrysocolla

therefore required sulphidization. Sulphidization followed by xanthate flotation has been shown to recover tarnished chalcopyrite (Clark et al., 2000) and other sulphide minerals such as pentlandite (Newell and Bradshaw, 2007). Secondly, all the other oxide copper minerals except chrysocolla responded positively to the NaHS/xanthate flotation treatment. These findings are consistent with observations made by Kottgen and Bastin (2009). In this context, the floatability of a relatively pure sample of a typical copper oxide mineral before and after sulphidization is clearly of interest. Microflotation tests with NaHS and SIBX (Figure 7) showed clearly that malachite, which is a typical example of such a mineral, was recovered after NaHS/xanthate (sulphidized) treatment but that chrysocolla did not respond positively to such treatment. Unsulphidized refers to tests done with only xanthate addition. Clearly, any chrysocolla that reported to the concentrate after sulphidization would do so due to its association with chalcopyrite, and not due to true flotation.

\section{Conclusion}

The objective of this study was to investigate the floatability of a complex Kansanshi mixed copper ore comprising sulphide and oxide minerals with a view to achieving maximum copper recoveries and grades. The major focus of the study was on the use of two different methods of sulphidization, viz. slug addition and controlled potential sulphidization (CPS). In all cases the addition of NaHS, irrespective of the addition procedure used, resulted in higher recoveries of $\mathrm{Cu}$. Slug addition at $500 \mathrm{~g} / \mathrm{t}$ resulted in a slightly higher $\mathrm{Cu}$ recoveries than at $250 \mathrm{~g} / \mathrm{t}$, but in both cases the grades were similar to that with only SIBX as collector. The CPS method resulted in an increase in $\mathrm{Cu}$ recovery but a decrease in grade compared to slug sulphidization. Mineralogical analysis of the tailings samples obtained after sulphidization showed no residual chalcopyrite, and that a significant amount of oxide minerals had been collected. Microflotation studies showed that sulphidization favoured the recovery of malachite but not of chrysocolla. This suggests that the increase in copper recovery after sulphidization was a result of the flotation of chalcopyrite that had not responded to xanthate treatment, due possibly to some degree of tarnishing.

\section{Acknowledgements}

The assistance of the Julian Baring Scholarship Fund (JBSF) and First Quantum Minerals Ltd. (FQML) is acknowledged with thanks.

\section{References}

BECKER, M., HARRIS, Wiese, J., and RAMonotsi, M. 2014. Investigation into the mineralogy and flotation performance of oxidised PGM ore. Minerals Engineering, vol. 65. pp. 24-32.

Broughton, D.W., Hitzman, M.A., and Stephens, A.J. 2002. Exploration history and geology of the Kansanshi $\mathrm{Cu}(-\mathrm{Au})$ deposit, Zambia. Integrated Methods for Disccovery: Global Exploration in the Twenty First Century. 1st edn. Goldfarb, R. and Nielsen, R. (eds). Special Publication 9. Society of Economic Geologists, Boulder, CO. pp. 141-153.

Buswell, A.M., Bradshaw, D.J., Harris, P.J., and ЕкмекCI, Z. 2002. The use of electrochemical measurements in the flotation of a platinum group minerals (PGM) bearing ore. Minerals Engineering, vol. 15. pp. 395-404.

CHABUKA, C. and WitiKA, L.K. 2001. Optimisation of the Baluba East ore treatment. African Journal of Science and Technology, vol. 1, no. 4. pp. 36-42. 


\section{The role of pulp potential and the sulphidization technique}

Chavez JR, W.X. 2000. Supergene oxidation of copper deposits: zoning and distribution of copper oxide minerals. Society of Economic Geologists Newsletter, vol. 41, no. 1. pp. 10-21.

Clark, D.W., Newell, A.J.H., Chilman, G.F., and Capps, P.G. 2000. Improving flotation recovery of copper sulphides by nitrogen gas and sulphidisation conditioning. Minerals Engineering, vol. 13, no. 12. pp. 1197-1206.

Ferron, C.J. and Manu, N.N. 1994. Recovery of copper oxide minerals by sulphidisation flotation. Reagents for Better Metallurgy. Mulukutla, P.S. (ed.). Society for Mining, Metallurgy \& Exploration, Littleton, CO. pp. $156-164$.

HoPE, G.A., Woods, R., and PARKER, G.K. 2010. Interaction of hydroxamates with malachite. ECS Transactions, vol. 28, no. 6. pp. 27-37.

Hope, G.A., Buckley, A.N., Parker, G.K., Numprasanthai, A., Woods, R., and McLEAN, J. 2012. The interaction of n-octanohydroxamate with chrysocolla and oxide copper surfaces. Minerals Engineering, vol. 36-38. pp. 2-11

JoNES, M.H. and WooDcock, J.T. 1979. Control of laboratory sulphidization with a sulphide ion-selective electrode before flotation of oxidised lead-zincsilver dump material. International Journal of Mineral Processing, vol. 6. pp. 17-30.

KotTGen, A. and Bastin, D. 2009. Mineralogical analysis of the "Red Ore" flotation circuit - Kansanshi. University of Liege. http://hdl.handle.net/2268/155492

LEE, J.S., NAGARAJ, D.R., and CoE, J.E. 1998. Practical aspects of oxide copper recovery with alkyl hydroxamates. Minerals Engineering, vol. 11, no. 10. pp. 929-939.

LeE, K., Archibald, D., McLean, J., and Reuter, M.A. 2009. Flotation of mixed copper oxide and sulphide minerals with xanthate and hydroxamate collectors. Minerals Engineering, vol. 22, no. 4. pp. 395-401.

McKeown, D.A. X-ray absorption spectroscopic study of copper in an amorphous coppe rsilicate: chrysocolla. Journal of Non-Crystalline Solids, vol. 180 , no. 1 . pp. $1-10$.

NAGARAJ, D.R. and GoRKEN, A. 1991. Potential-controlled flotation of and depression of copper sulphides and oxides using hydrosulphide in nonxanthate systems. Canadian Metallurgical Quarterly, vol. 30, no. 2 pp. $79-86$.

Newell, A.J.H. and Bradshaw, D.J. 2007. The development of a sulfidisation technique to restore the flotation of oxidised pentlandite. Minerals Engineering, vol. 20. pp. 1039-1046. DOI:10.1016/j.mineng.2007.04.012
O'MeAra, A. 1961. A mineralogical approach to Copperbelt metallurgical problems. Proceedings of the 7 th Commonwealth Mining and Metallurgical Congress, Kitwe, Zambia. Watts, W. (ed.), Institution of Mining and Metallurgy, London. pp. 333-383.

PhetLA, T.P. and Muzenda, E. 2010. A multistage sulphidisation flotation procedure for a low grade malachite copper ore. International Journal of Chemical, Molecular, Nuclear, Materials and Metallurgical Engineering, vol. 4 , no. 9. pp. 580-586.

Quast, K.B., Tsatouhas, G., Wong, K.Y., and Newell, R. 2005. The use of polysulfide as an alternative sulfidising reagent for the CPS flotation of oxide copper ores. Proceedings of the Centenary of Flotation Symposium, Brisbane, Australia, 6-9 June 2005. Johnson, G.J. (ed.). Australasian Institute of Mining and Metallurgy, Carlton, Victoria. pp. 1027-1032.

Reich, M., Palacios, C., Vargas, G., Luo, S., Cameron, E.M., Leybourne, M.I., and You, C. 2009. Supergene enrichment of copper deposits since the onset of modern hyperaridity in the Atacama Desert, Chile. Mineralium Deposita, vol. 44. pp. 497-504.

SchWARZ, A. 1905. Process of concentrating ores. US Patent US807506.

Selley, D., Broughton, D., Scott, R., Hitzman, M., Bull, S., Large, R., and BARRA, F. 2005. A new look at the geology of the Zambian Copperbelt. Society of Economic Geologists, 100th Anniversary Volume. Hedenquist, J.W., Thompson, J.F.H., Goldfarb, R.J., and Richards, J.P. (eds). pp. $965-1000$.

SoTo, H. and LASKOWSKI, J.S. 1973. Redox conditions in the flotation of malachite with sulphidizing agent. Transactions of the Institution of Mining and Metallurgy Section C-Mineral Processing and Extractive Metallurgy, vol. 82. pp. C153-C157.

Speiser, A., Hein, U.E., and PoradA, H. 1995. The Kansanshi Copper Mine (Solwezi area, northwestern Zambia): Geology, wall-rock alteration and fluid inclusions. Mineral Deposits; from their Origin to their Environmental Impacts. Proceedings of the 3rd, Biennial Meeting: Society for Geology Applied to Mineral Deposits. Pasava, J., Kribek, B., and Zak, K. (eds), Society for Geology Applied to Mineral Deposits (SGA), Prague. pp. 389-392.

WenBIN, Z. 1993. Thirty-year plant practice of sulphidisation - flotation of copper oxidised ores. Proceedings of the XVIII International Mineral Processing Congress, Sydney, Australia. Australasian Institute of Mining and Metallurgy, Melbourne. pp. 23-28.

Wills, B.A. and NAPIER-Munn, T. 2006. Wills' Mineral Processing Technology. 7th edn. Elsevier, Oxford. 